133.

骨撮影における新オルソシステムの比校娭討

The Comparition Stady Of New Orthochromatic Systen In Osseous ragiorography

公立八鹿病院 中央放射線部 ○上仲彰洋 小谷康仁 田野貞広上田政己

[目的]従来当院において骨撮影はレキュュラーシステムを用いていたが、粒㧋性、鲜鋭度に優れたADシステム(HGMＵR-2）の導入によ り画賀の向上が得られた。今回、骨撮影におけるフシHGMスクリーンでのフシUR-2とコタックIEF-RAを物理的、視覚的に比校梌討を 行ったので報告する。

[万法] 1 物理的評任は、特性曲缐、MTF、RMSを比校検討した。

2 钼覚的評俰は、手、頭部、腰推を同一涱度になるように撮影し、それぞれをコントラスト、鲜鋭度、粒状性、解像度を䛌 療放射線技師13名、放射缐科医師2名にて比較検討した。

[結果]IEF-RAはUR-2に比へよりよく骨梁が描出でき、骨撮影において良好な結果が得られた。

134.

上部消化管撮影における新才ルソシステハす比較梌討

Conparative study of New aO Syste in upper 61 series

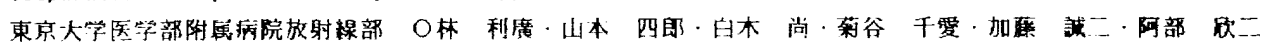

[目的]フジフィルムより新しく開発された消化管用フィルムと A D システム（H G M + U R 2) 及び従来システム ( H R - 4 + S HR - S ) との比較検討を行う。

[万法]（a）物理特性टして特性曲線・MTF・WS 值を求める。（b）撮影管電压を5段階に変化させ、マーゲ ンファントームを撮影し各システムごとの視覚泙価を行いそれぞれのシステムの最道管電压を求める。 (c) bで得られた各システムのフィルムについて更に視覚評価し、物理特性と合わせて検討する。

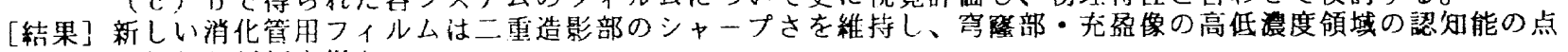
で優れた評他を得た。

135.

\title{
新開発フィルム(MX TEST)の臨床評価
}

Clinical evaluation of new ortho-film (MX TEST)

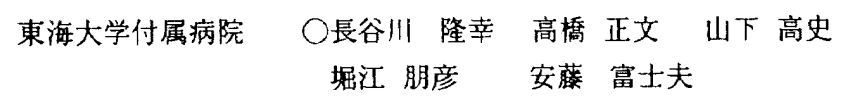

【目的】Fuji AD-system 対応の新しいつ伀が開発され使用する機会を得たので, 臨床適応について検 討する。

【万法】 AD-system (HGM+UR-1,UR-2,MX TEST) とSuperHR沙-ズ (HR-4+sHR-L30,sHR-S30)について腹部単純撮影, 骨撮

影,腹部消化管造影を行い,それぞれの撮影における最適な7价ムース沙ーン系の検討を行う。

【蛣果】新開発つ价ム(MX TEST)は，腹部撮影領域において有用であると思われ、現在も引き続き検討中である。

136. 低度セロクロスオーパーフィルムを用いた或材システムの検討

(新高感度增感林との相み合わせについて)

Study of Photosensitive Vaterial System ith Lon speed/Lon crossover film

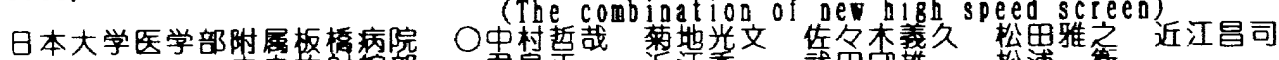

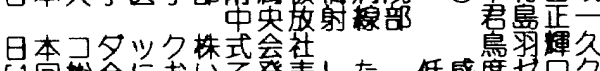

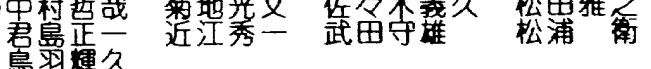

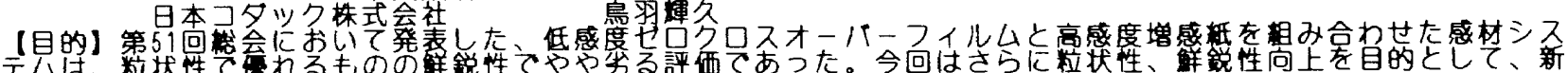

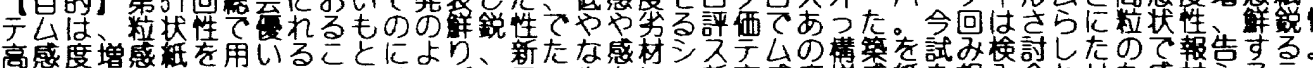

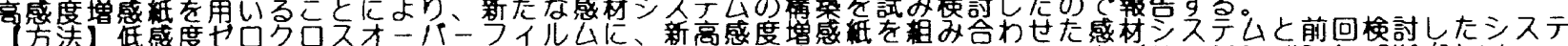

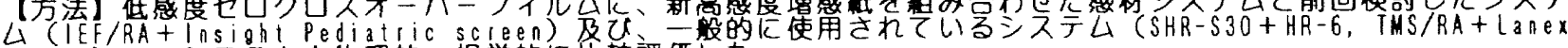

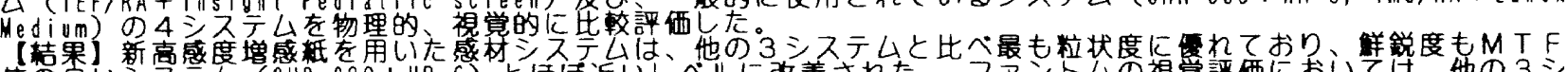

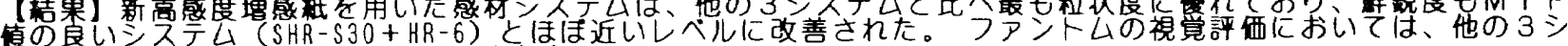
六元と比して、概桹好な評他を得た。 